\title{
The Governor-General's Apology Reflections on Anzac Day
}

\section{GeRHARD FISCHER}

UNIVERSITY OF NEW SOUTH WALES

...nicht fürchtend die unreine Wahrheit...

(...not fearing the impure truth...)

Heiner Müller, Der Horatier ${ }^{1}$

-I. THE IMPURITIES OF THE PAST

The late, great German playwright Heiner Müller, successor to Bertolt Brecht, reminds us that history, like other constructions of the human mind, is seldom clean or pure. But the impurities of the past, Müller insists, must be faced and addressed squarely. We cannot accept a dry-cleaned or sanitised version of the past, prepared for public consumption by historians or politicians or so-called media personalities, for their own ideological ends or to suit the agenda of their sponsors. We must fearlessly observe and study the events of the past, the motivations and actions of its protagonists, the alternatives realistically available and if, for instance, a particular person is a national hero and at the same time the murderer of his sister, as the Horatian of Müller's play that recalls the barbaric times of early Roman history, then that same person must be both praised and punished, and he must be remembered 
both as a patriot and as a killer. Above all, says Müller, 'the words must remain pure' ('die Worte müssen rein bleiben'). ${ }^{2}$

\section{-II. THE GOVERNOR-GENERAL'S APOLOGY}

On 26 September 1999, the then governor-general of Australia, Sir William Deane, delivered the opening address at the inaugural Australian Conference on Lutheran Education (ACLE) at a Gold Coast resort in Queensland. ${ }^{3}$ In his speech, the GovernorGeneral offered an apology to members of the German Australian community present at the meeting:

The tragic, and often shameful, discrimination against Australians of German origin fostered during the world wars had many consequences. No doubt, some of you carry the emotional scars of injustice during those times as part of your backgrounds or family histories. Let me as GovernorGeneral, say to all who do how profoundly sorry I am that such things happened in our country. ${ }^{4}$

The statement invites reflection on a number of issues, most importantly, I believe, on our understanding of the Anzac historiography and its various narratives. That the apology is little known is perhaps not surprising, given that it was made to an inhouse conference of Lutheran clergy and educators, and that it was certainly a personal initiative of Sir William Deane of which neither the government nor the media of the day took any notice. On the other hand, the Lutheran Church in Australia has always been the most representative organisation linked to the German Australian community. If a governor-general, expressly speaking as such, offers an apology to such a group at an official function, it is certainly more than a private matter.

One might argue about the weight that the speech carries. The governorgeneral speaks to and for all Australians. But Deane's apology is obviously not of the same status as the 'Sorry Speech' of Kevin Rudd that was delivered in the federal parliament by the prime minister on behalf of the government and the nation. Nor can it be compared to a political act such as the bill passed by the US House of Representatives that offered an apology for the unlawful internment of Japanese Americans during World War II. In the Civil Liberties Act, the US Congress acknowledged that government action of the day was based on race prejudice, war 
hysteria and a lack of political leadership. Much the same could be said about Australia, in World War I in particular, and the governor-general's apology can certainly be read as implying a similar critical intent. It confirms the statement Deane made shortly after his appointment in 1996: 'National shame, as well as national pride, can and should exist in relation to past acts and omissions.' 5

William Deane certainly was an outstanding and outspoken modern head of state who fulfilled this role in an exemplary manner. In Heiner Müller's terms, he fearlessly addressed the impurities of the nation's past, notably in his concern for the welfare of Australia's weakest and most disadvantaged groups. Above all, he stressed the necessity to come to terms with the continuing problem of the historical injustice suffered by the Aborigines, an issue that he often chose to link to his other favourite cause, the advocacy of Australian multiculturalism. As he put it in one of his speeches: 'Attitudes towards, and the circumstances of, Indigenous Australians lie at the very heart of a responsible national multiculturalism.' ${ }^{6}$

So what are we to make of Deane's apology today? In the context of Anzac Day and the forthcoming centenary of the start of World War I, the apology may serve as a timely reminder of a part of the history of Australian participation in World War I that has been all but forgotten. Along with other narratives that contribute to the totality of the Australian war experience, the story of a home front war waged against the German Australian community has been overshadowed by the monolithic Anzac narrative and the web of myths and legends that have been constructed around it. The most poignant-and perhaps astonishing-aspect of the governor-general's apology is that it was made not by a critic of the Anzac legendof which there are many-but by one of its most ardent supporters and eloquent spokespersons. How can we balance Deane's apology for the injustice and discrimination suffered by German Australians during World War I with his firm belief in the importance of the war experience of the Australian Imperial Forces (AIF) at Gallipoli: the 'spirit of Anzac', in his words, constitutes the 'linchpin' of Australian national identity.7 I believe there is an inconsistency here that I shall return to. 
- III. The destruction of the German Australian community in World War I

Australian school children today know much about what happened at Anzac Cove and Lone Pine in 1915, but they know very little about what happened in Australia itself at that time. A total of 6,890 people came to be interned in Australia during World War I, and a total of 6,150 were deported after the end of the war. Of these, about four and a half thousand had been Australian residents before August 1914. They included approximately seven hundred 'naturalised British Subjects' and seventy 'Native Born British Subjects' who were Australian by birth, sometimes second- or even third-generation Australians. William Morris Hughes, prime minster of the day, repeatedly, and proudly, proclaimed that Australia had interned more socalled enemy aliens, on a pro capita basis, than had been imprisoned in the United Kingdom and the United States of America. ${ }^{8}$

Internment and deportation were only two, albeit the most drastic, of a whole range of discriminatory measures enacted against 'enemy aliens'. ${ }^{9}$ In August 1914, all Germans and Austrians living in Australia were required to report to the nearest police station and register as aliens by completing a form with their personal particulars. The local police then imposed a number of restrictions; suspected aliens usually had to report to the station, daily or weekly. The whole procedure was seen as a blemish on a registrant's reputation; in the end, it had the effect of stigmatising the whole community of German Australians, the largest non-British group of immigrants in Australia at the time.

Economically, the war provided an opportunity to realise the Prime Minister's long-held aim of eradicating 'German influences from the trade of all parts of the Empire', by diverting 'trade from enemy to empire', as Hughes put it. ${ }^{10}$ The government designed legislation not only to prevent Australian products from reaching Germany during the war, and vice-versa, but also to destroy what were considered German firms operating in Australia, regardless of whether they were branches of foreign companies or founded in Australia and run by Australian residents. Various pieces of legislation passed between 1914 and 1918 prohibited enemy aliens from buying or selling land and owning or managing businesses. Suspected persons were ordered to disclose holdings in shares or bank accounts. ${ }^{11}$ In parliament, Hughes was not afraid to point out that the war was being fought for 
economic supremacy; this was an argument to support the Australian government's unreserved commitment to the war, rather than to oppose it. ${ }^{12}$

The particular experience of Australians at war at home needs to be contrasted with the development of an Australian nationalism generated by the Anzac story, the foundation myth of Australian nationhood that today has developed into a kind of national civil religion. The Australian story of the home front war offers a sobering counter projection to the story of the heroic Anzacs overseas. While the Australian soldiers at Gallipoli are said to have discovered their mateship and loyalty to each other as defining features of their sense of self, Australians at home were encouraged by their government to 'dob in' their German Australian neighbours who had been their mates only a few weeks earlier. Many did so with great enthusiasm, driven by an exaggerated fear for the country's safety, but also by a felt need to become involved in an adventurous mission: to participate in the affairs of the world from which the isolated colonial outpost of the British Empire had been largely excluded in the past. While the AIF soldiers are said to have discovered a sense of their independent Australian identity, as distinct from their 'Britishness', the Australian government pursued a policy of ethnic homogenisation, designed to preserve Australia for an imagined British race and to link the country more closely to the British Empire. In September 1919, Hughes spelled out his vision in a speech in the federal parliament:

We are more British than the people of Great Britain, and we hold firmly to the great principle of the White Australia, because we know what we know. We have these liberties, and we believe in our race and in ourselves, and in our capacity to achieve our great destiny, which is to hold this vast continent in trust for those of our race who come after us. ${ }^{13}$

Hughes' aim of creating a society that was exclusively British in its ethnic, 'racial' and cultural make-up was largely realised. World War I confirmed the British destiny of the Australian people; it was to be a home for white Australian 'Britishers', monocultural and monolingual, there was no room for anything else. The war for White Australia had been won by the Anzacs in the killing fields of Flanders, Hughes later claimed, and he had come home from Versailles with the written guarantee that confirmed the victory. 
World War I interrupted a uniquely Australian experiment in pluralistic and multicultural democracy that had begun around the middle of the nineteenth century and which received a strong boost in the 1890s with the formation of an Australian national identity in statu nascendi. This was not a monolithic, simplistic identity: it could be defined as 'modern', it was characterised by a 'unified spirit', but was nevertheless open to cultural diversity and alternative cultural traditions. ${ }^{14}$ Whereas the Anzac narrative proclaims a breakthrough towards a new period in Australian history, indeed the founding of the nation, the destruction of the German Australian community in World War I confirms the end of an innovative era; it is a step backward, a return to the old, pre-1890s attitudes and values, resulting in a strengthening of the previously dominant pattern of Anglo-conformity and insistence on immigration from the British Isles. ${ }^{15}$ This pattern became the dominant mode of cultural identity in the decades between the world wars. It was reinforced with the internment of enemy aliens during World War II.16

\section{-IV. AnZAC DAY AS NATIONAL DAY}

How can one explain the unique success of the Anzac story as the foundation myth of Australian nationhood and the basis for the country's de-facto national day? Mark McKenna, who has traced the evolution of the Anzac story, attributes its endurance and resurgence to the evolution of its message that was reshaped by succeeding generations for their own purposes. ${ }^{17}$ Graham Seal has offered a similar argument by demonstrating the 'malleability' of the Anzac Day dawn service 'that allows it to be adapted for a variety of purposes' by appealing to different 'stakeholders' in the Anzac ritual: the military, the clergy, ex-servicemen, and grieving civilians: 'The existence and persistence of ... several originary narratives [of the dawn service] reveals the major players in the mythology of Anzac and helps to explain why the dawn service has such widespread appeal.'18

To those alive during World War I it was obvious that the Anzacs were fighting for King and Empire; this part of the story needed no explanation. To Charles Bean and his followers, who invented the Anzac cult, it meant primarily a celebration of Australian manliness, the discovery of an imagined national character in the image of the man from the bush: laconic, tough, egalitarian and loyal to his mates, with a talent for larrikinism thrown in for good measure. ${ }^{19}$ Today's Anzac is very different: 
it offers an all-inclusive experience of Australian multicultural togetherness-a powerful motive in a society characterised by increasing diversity that is sometimes seen as threatening or antagonistic. As the employment opportunities offered by the Armed Forces have increased over the years, more and more people have become eligible to establish a connection to the Anzac tradition, as veterans or their friends and families: men and women, Aborigines, migrants, gay people. ${ }^{20}$ Today, young and old representing all social groups take part in Anzac Day marches, even children dressed up as mini-diggers, waving flags while clutching the hands of their uniformed parents or grandparents, have become part of the annual Anzac iconography. This is where the governor-general's apology fits in as well. Australians of German background, previously stigmatised as enemy aliens, can see it as an invitation to be welcomed back into the Broad Australian Church, invited to embrace the 'Anzac Spirit'.

In more recent years, politicians have increasingly used Anzac as their own platform. Australian prime ministers from Bob Hawke onward have made the annual pilgrimage to Gallipoli to take part in the beachside dawn ceremony, of course accompanied by an ever-growing media pack that ensures the message is dutifully received at home. In 2012, Julia Gillard went to Gallipoli to confirm what many commentators had already predicted in previous years, that Anzac Day had become 'more significant than Australia Day, both emotionally and in terms of the values it represents'. ${ }^{21}$ Paul Keating was the only prime minister to step out of line, by attending the Anzac Day dawn service at the Bomana Cemetery (Port Moresby) near the beginning of the Kokoda Trek, on 25 April 1992.22 The suggestion that Kokoda should take the place of Anzac was a worthy effort, as Keating was certainly right in pointing out that the vital security of Australia was at risk in World War II, which was clearly not the case in World War I, and that in the New Guinea campaign Australian soldiers were indeed fighting in defence of their own country for the first time. But Kokoda had already been integrated into the larger Anzac narrative that now claims all the wars Australia took part in, and it is difficult to see how the Kokoda story could be stretched to match the elaborate mythology that has grown around the Anzac legend as the foundation of an Australian national consciousness and identity. 
In 1999, the governor-general also went to Gallipoli to preside over the dawn service. In his address, Sir William Deane defined the meaning of Anzac:

Anzac is not merely about loss. It is about courage, and endurance, and duty, and love of country, and mateship, and good humour and the survival of a sense of self-worth and decency in the face of dreadful odds. These were the qualities and values the pioneers had discovered in themselves in what were, for Europeans, the new lands of Australia and New Zealand. They were tested here [at Gallipoli] and in the ancient battlefields of Europe for the first time in the Great War. They were not found wanting. ${ }^{23}$ The passage is remarkable as much for its historical encryption as for the way it succinctly captures the essence of the original Anzac mythmaking. Its rhetoric recalls the first construction of the legend by Charles Bean who had also found the supposedly typical Australian characteristics in the earlier generations that preceded the soldiers of 1914. Deane does not speak of the 'men from the bush' and their 'manly' attributes; instead, he speaks of 'pioneers'. ${ }^{24}$ But who were these pioneers, if not the convicts and their guards and the free settlers, the selectors, squatters and pastoralists, the gold rush adventurers and migrants who had come to Australia during the nineteenth century, not only from the British isles but from many countries around the globe? The use of 'pioneer' as a single, homogenising metaphor glosses over the complexities and the rich diversity among the nineteenth-century Australian nation-builders. Deane does recognise the prior ownership of the country by Indigenous Australians, but he stops short of referring to the way the land was colonised by violent conquest. In any case, the subsequent shift of focus to the AIF soldiers tends to obliterate the achievements of the earlier 'pioneers' altogether. All attention is now on Anzac and on Australia's role in World War I, the impurities of Australian history in the nineteenth century are overlooked, and in the process civilian virtues are redefined in a military context.

In the final phase of this remarkable metaphorical-historical transformation, the national is invoked: the landing of the AIF at Gallipoli and the subsequent military engagement with the Turkish forces give rise to the 'spirit of Anzac' - the birth of the nation out of bloody warfare. In the rhetoric of Anzac, mourning gives way to national pride. As the governor-general put it in his speech at the Australian War Memorial in October 2000, at the opening of the 'Forging the Nation' exhibition, 
World War I was the 'pivotal event' for the young nation that had come together in federation in 1901:

The suffering and loss of that war, which affected nearly every Australian family, was accompanied by-indeed, was even a source of-real national pride and emerging national identity. It was pride in the achievement of our young nation and its soldiers. Pride in the conviction that death and suffering had not been in vain, pride in what, since the disaster of Gallipoli, has often been seen as the 'Spirit of Anzac'. 25

\section{-V. Celebrating Anzac as secular Easter}

According to Mark McKenna, John Howard, as prime minister, played a special, indeed 'revolutionary' role in shaping the evolving Anzac narrative. By 'using Anzac Day as a vehicle for national self-congratulation', McKenna writes, Howard introduced a new '“celebratory" tone into Anzac Day'.26 Previously, the emphasis was on the commemoration of loss, of mourning and paying respect to the dead, indeed on the notion of an 'Australian All Souls' Day'. This is how Canon David John Garland, who was responsible for the original liturgical shaping of Anzac Day rituals as a Eucharistic Requiem while acting as secretary of the Brisbane Anzac Day Commemoration Committee in 1916, originally envisaged the event. ${ }^{27}$ In contrast, the speeches of Howard increasingly claimed that the Anzac tradition had supposedly generated a spirit of enrichment and rejoicing, a change of emphasis that seems to have been broadly accepted. Today, it is not at all uncommon to hear people greeting each other with 'Happy Anzac Day'. Thus, Anzac Day imperceptibly merged with or, perhaps better, took over Australia Day with its 'Celebration of a Nation' slogan. Following Howard's 2003 speech, Anzac Day began to be described in the media as the day 'which salutes the country itself', the day on which the Australians 'celebrate' their founding generation'.28

I think it is quite right to emphasise the interventionist role of Howard, but I also believe that the tendency, if less overt, to turn mourning into celebration has always been an inherent feature of the Anzac cult. In essence, this is captured in Donald Horne's metaphor of Anzac as 'secular Easter'. ${ }^{29}$ Anzac, like Easter, is about death and mourning, but also about resurrection, victory and celebration. To be sure, the Gallipoli landing was a 'fiasco' and a 'disaster'. ${ }^{30}$ The best that could be said 
about it in purely strategic terms is that it ended in an orderly retreat. It was alsolest we forget-a Schlacht, to use a German word favoured by Heiner Müller, meaning both battle and slaughter, a carnage on both sides. But out of a senseless slaughter the Australian soldiers rose to fight on in France, to face an even more horrific carnage, to eventually emerge on the side of the winners, exhausted but triumphant, lucky survivors.

Thus, and this is a further factor that explains the success of Anzac as national narrative, Australia's participation in World War I ends on a positive note: we won. The dead are not forgotten of course and will be duly remembered, but what matters is that Anzac, in the end, delivers a feel-good story. We belong to the winning side, indeed we are the winners if we take the title of John Monash's book The Australian Victories in France at face value. ${ }^{31}$ Australians, so the story goes, are on the right side of history, have made the world safer for democracy and-let's not forget-have put the country firmly on the map of global politics, as Billy Hughes certainly believed he was doing when, at the Versailles Conference, he played the recalcitrant colonial and loudly voiced his angry opposition to the 'equality of races' clause-proposed for the Covenant of Nations-in order to assure a future White Australia. Playing politics on the world stage is an integral part of the Anzac narrative. I suspect it is today no less than before a strong motivation for Australian leaders to send Australian troops overseas to follow in the footsteps of the Anzacs to fight other people's wars.

There are other factors that add to an explanation of the success of the Anzac narrative, such as the promotional role of the media in recent years, or the extraordinary activities of the Department of Veterans' Affairs in sending out brochures and other 'educational' materials to schools all across the country to ensure that Australian children are inoculated with the officially sanctioned version of Anzac. In What's Wrong with Anzac?, Marilyn Lake and Henry Reynolds have criticised these and similar government activities as inappropriate; arguing they amount to a kind of state propaganda campaign that has resulted in an unprecedented 'militarisation' of Australian history in the national syllabus and research agenda. ${ }^{32}$

The latest phase in the transformation of Anzac Day into a popular national holiday seems to be the hijacking of the event by the commercial television media 
organisations. In 2008, as Graham Seal has shown, Channel 7 broke new ground by staging a local ceremony at Elephant Rock on Currumbin Beach, Queensland:

This dawn service was broadcast by the Channel 7 infotainment Sunrise program and bore all the signs of a media event. It was billed as 'the Gold Coast's largest free Anzac Day commemoration', as 'an unforgettable service', and as a 'world-renown event'. The Sunrise website claimed that 'Sunrise viewers all around the nation will be able to partake in this service to honour our diggers and their families'. An estimated 10,000 people attended the event, Elephant Rock having over time become the preferred local site for this observance despite having no apparent memorial or other Anzac connection. The 'service' appeared to be without any formal religious participation and had the character of a popular celebration of national identity of the kind usually associated with Australia Day. Crowds of lifesavers attended in their colours and with their banners, the crowd was well prepared with small Australian flags and in some cases, draped larger flags around their shoulders. ${ }^{33}$

I should like to add one more observation that, in my opinion, is perhaps underappreciated in an explanation of the recent rise of Anzac as undisputed national day. The Anzac experience is apparently able to generate a strong emotional affect that seems to fulfill a need felt by many of its participants, including young adults with little or no actual connection to an experience of war. Many observers at recent Anzac commemorations have commented on this phenomenon, and I believe it needs to be taken seriously. The wonderfully warm and fuzzy feeling generated by a sense of belonging and communal bonding seems to be an essential part in a process of recognition of identity. Being acknowledged and accepted as part of a group is a very satisfying outcome. ${ }^{34}$ There is no denying the emotional appeal and integrative power of nationalism, and this can be a good thing, provided it serves a higher, common goal such as independence or national liberation. But emotionalism must be accompanied by knowledge, reflection and critical, including self-critical, analysis.

Today's sanitised version of the Anzac narrative is a celebration of history purged of impurities. There is no mention that World War I was fought for the interests of Empire and the sub-imperial aims of the Commonwealth Government of 
the day. There is no mention of the racist context of White Australia. No mention is made of the participation of the AIF in wartime massacres or of the role of Australian soldiers in suppressing anti-British independence movements, both in the Middle East and in Ireland. ${ }^{35}$ Little regard is paid to the suppression of civil liberties and oppressive censorship at home, to the internal social divisions within the country created by the war, and less to the persecution of the German Australian minority-the governor-general's apology notwithstanding. One might ask whether the young Aussie backpackers, or adults for that matter, who are finding emotional fulfillment in the community of mourners and celebrants at dawn services at Gallipoli and all around Australia, have any clear idea about the horrors of dying in World War I. Above all, one needs to ask the 'ultimate question', to quote McKenna again: 'Does Australia, a modern pluralist society in the twenty-first century, still wish to cling to the nineteenth-century concept of nationhood: the belief that a nation can only be truly borne through the spilling of the sacrificial blood of its young?' 36

-VI. A new national day for Australia

On Anzac Day 1981, Donald Horne published his article 'A Challenge to the Anzac Legend'. He concluded that both Anzac Day and Australia Day are unsuitable as a national day for Australia:

Australia Day, no matter how much we may try to hide it, is now seen as celebrating the beginning of the British occupation of Australia. Anzac Day celebrates not only comradeship and sacrifice, but also remembers Australian fealty to Britain. Both days celebrate not independence, but dependence.

One way out would be to give up attempting to have a national day. ${ }^{37}$

I must admit I am not entirely sure how to read Donald Horne's rather abrupt conclusion. Could it be that Horne has spoken here as a rational, critical intellectual who is perhaps too easily dismissive of the emotional appeal and power of a celebration of national pride? Why is it that Australia should not have a national day when everyone else seems to have one? 'National holidays ... are powerful symbols that create meaning and myth, that shape historical imagination'.38 
The problem is that Australia Day needs to be reinvented and filled with new meaning. If 26 January was to be truly the national day of Australia, Aboriginal opposition to what is seen as Invasion Day needs to be addressed, the legacy of empire and colonialism needs to be worked out, and the role of the convicts and early settlers as the true founding fathers and mothers of the colony must be acknowledged. This seems perhaps all a little too much to ask at once, but historical truth, as Heiner Müller reminds us, is indivisible: the 'words must remain pure'. If Anzac Day has evolved the way it did over almost a century now, why cannot Australia Day evolve to become a true national day? Perhaps we need to look towards the future to explore how this could happen, as it should in my opinion. I think two basic conditions must be met. The first is a resolution of the Aboriginal issue that both recognises prior ownership (sovereignty) in a constitutional document, and that makes a firm commitment towards real improvements in material matters (health, education, employment, and so on) for Indigenous people. This is a work in progress, of course, even though the progress appears painfully slow. The other condition involves another impurity of Australian history that is-if I am not mistaken-today rarely if ever addressed in terms of national celebration and commemoration, of national foundation stories, or role models for an imaginary national character.

In the summer of 1934/35, the Czech-German writer Egon Erwin Kisch visited Australia-readers might remember his Australian Landfall-and wrote of his impressions of Anniversary Day, as Australia Day was then known. Kisch found widespread confusion as to what was actually being celebrated by the festive crowds along the harbour and in the parks of Sydney on, as he eventually puts it, 'the day on which, for the first time, a cargo of chain-gang convicts was unloaded upon the Australian shore'. ${ }^{39}$ Kisch's brutal metaphor reminds us why Australians in the 1930s found it difficult to confront what many felt was a shameful past better to be forgotten. The historical truth of convictry is not one that is easily dealt with. Kisch's contemporaries certainly were fearful of this unclean history and preferred to believe in an alternative foundation narrative. Even at the bicentennial Australia Day commemoration, the Sydney Morning Herald found an 'ideological vacuum' at the 'heart of the celebrations', a diagnosis that is remarkably similar to Kisch's conclusion. ${ }^{40}$ Kisch, the outside observer, had no problem identifying the convicts, 
along with the settlers who followed in their footsteps, as the pioneers, the ancestors of contemporary Australians. He compared the convicts to the Mayflower Pilgrims of North America, and wrote:

Certainly, among the convicts there were some who had grave misdeeds behind them, but even these have done everything humanly possible to make things easy for their grandsons. Convicts have revealed new land ... convicts have levelled and made the roads, discovered coal and cleared the forests, cultivated the fields and built the towns. They founded the first schools and created the first museum, the first books, the first newspaper ... they were the 'human power and the human mind' which is celebrated today with such discreet words. ${ }^{41}$

On 26 January 1935, Kisch found that the 'grandsons' or the Australians of the day do not remember their ancestors, even though 'those Ancestors ... have created the best that ancestors are able to create: a good posterity'. ${ }^{42}$ Kisch's description of a day in 1935 that has since become Australia Day offers a prescient cultural analysis of a society that was, until not very long ago, 'longing for amnesia'; it confirms the impression of an 'historical blankness', to quote Robert Hughes, that had taken hold of the country. 43

Acknowledging the foundational role of the convicts and early settlers would of course require recalling the role of Great Britain and the British Empire, which today is conveniently sidestepped in Anzac Day rituals. But it would do much more: it would focus the national attention on Australian history as one not shaped by war in a foreign land but by the building of a civil, multicultural society at home, with democratic institutions of self-government and a modern system of industrial relations that was once considered a model for other industrialised societies. It would also focus on the supposedly typical Australian virtues of fairness, egalitarianism and mateship, but it would not link these qualities to an experience of war.

In my opinion, such historical recognition can only happen in one way: by Australia declaring itself an independent republic, acknowledging and, at the same time, severing the last colonial constitutional connection to the crowned head of Great Britain, whoever that may be when it happens. The move towards a republic, lest we have forgotten, is also a work in progress, though it seems to be in a phase of 
prolonged hibernation at present. But for it to make a difference, the Republic-to-be would need to be more than the minimalist model envisioned by the Australian Republican Movement in the 1990s: it would need to have a political and social agenda, with a firm commitment towards Aboriginal reconciliation as its first priority. The foundation day of such a republic would be the first truly national holiday.

On this day, there will be a lot of mourning and grieving, a lot of reflection, and a lot to celebrate. On their first true National Day, Australians will acknowledge the Aborigines as the original guardians of the land and will affirm their own commitment to look after the country in a sustainable way, they will mourn the victims of European colonisation, reflect on the continuing grievances of Indigenous Australians, and they will solemnly re-affirm the process of reconciliation. They will recognise the achievements of the early settlers and mourn and commemorate the victims of convictry. Finally, they will celebrate their independence from their former colonial warden and the multicultural inclusiveness of all Australians.

So, there you have it: on 26 January 20XX, Australia will become a Republic, with a new constitution coming into effect that fearlessly addresses all the nation's past. To become involved in making such a vision a reality could warm the hearts and fire the imagination of a majority of Australians, including our young backpackers on their way back from Turkey, in a powerful way as much intellectual as emotional.

-VII. A PLACE for ANZAC DAY

There will always be a place for Anzac Day in the Australian calendar, because we need to remember and pay respect to our soldiers who died fighting in war. Sir William Deane has provided a model of inspiration for such a day of mourning which holds a special meaning for him. Cornelius Deane, Sir William's father, was one of the many soldiers who had come home from World War I a changed man. He was a hero, wounded and highly decorated, but had become withdrawn and silent. He refused to talk about his experiences, like many returned ex-servicemen who had found the horrors they had witnessed at the front too difficult to comprehend and to come to terms with. But Anzac Day, as his son recalled, was for the father 'truly the one day of the year': 'it is the day that I particularly associate with my father'. ${ }^{4}$ 
When Cornelius Deane died on Anzac Day 1962, he had left a profound and lasting impression on the young William Deane. It is this intensely private experience, the feeling of sadness and personal loss, of empathy with the survivors and their families, and an awareness of so many lives wasted in so many ways, that gives legitimacy to the public mourning on Anzac Day.

Such an Anzac Day would perhaps mean a return to its original roots, as envisioned by Canon David John Garland in his 1926 sermon at the unveiling of a 'Cross of Sacrifice' next to a 'Stone of Remembrance' at Brisbane's Toowong cemetery, the burial place of three hundred soldiers who had died from their wounds after their return to Australia:

There is no room for anything but a solemn observance of Anzac Day-the All Souls' Day of Australia-and so we come before God not in the bright vestments of festival and the joyous music of triumph; but with the tokens of Christian penitence and sorrow for the sin of the world which caused the sacrifice of those bright young lives, our dearest and our best. 45 According to Tony Stephens, 'no other governor-general has made a greater contribution to the Australian debate on values and social issues'.46 For this, the Australian people owe William Deane a profound debt of gratitude and respect. I think, though, that his public position regarding what he calls 'the spirit of Anzac', linking the birth of the nation and Australia's national identity to its participation in World War I, is not in the best interest of the Australian people. World War I was an 'inexcusable folly', as Paul Keating put it with admirable understatement. ${ }^{47}$ It certainly was not a Great War, though it is still referred to as such even today. There was nothing great about that war, certainly nothing to celebrate and to rejoice. There is nothing great about any war. 48

Gerhard Fischer is a senior research fellow in the School of International Studies at the University of New South Wales and Fellow of the Australian Academy of the Humanities. A literary scholar and historian, he has published on World War I (Enemy Aliens, 1989) and nineteenth-century Australian migration history, on 
multiculturalism and on modern German and European literature, drama and theatre. Recent publications include W.G. Sebald: Schreiben ex patria / Expatriate Writing (2009) and, with Nadine Helmi, The Enemy at Home: German Internees in World War I Australia (2011), which won the 2012 National Trust Heritage Award and is currently shortlisted for a 2012 NSW Premier's Literary Prize.

\footnotetext{
-NOTES

1 Heiner Müller, 'Der Horatier', in Heiner Müller, Mauser, Rotbuch Verlag, Berlin, 1978, pp. 45-54.

2 Ibid., p. 53.

3 I am indebted to Peter Rechner, Melbourne, for making me aware of the apology and for tracking down the published source of Deane's speech (The Lutheran, 25 October 1999), with the help of Lyall Kupke of the Lutheran Archives, Adelaide.

4 I am grateful to Sir William Deane for having provided me with a copy of the full text of his speech.

${ }^{5}$ Quoted in Tony Stephens, Sir William Deane: The Things that Matter, Hodder, Sydney, 2002, p. 2.

${ }^{6}$ Sir William Deane, 'Australia's Multiculturalism: Time for Assessment and Renewal', 2005 Vice-

Chancellor's Oration, Winthrop Hall, University of Western Australia, 21 March 2005,

<http://www.hr.uwa.edu.au/equity?f=69859>.

${ }^{7}$ Sir William Deane, Directions: A Vision for Australia, St Pauls Publications, Strathfield, NSW, 2002, p.

22.

${ }^{8}$ In the United States, a total of 6,300 men were interned as enemy aliens during World War I, including 4,000 German crew members taken off ships and 2,300 civilian German Americans (out of a total 'eligible' population of eight million US residents of German ancestry, including 2.5 million born in Germany). Cf. Jörg Nagler, 'Internment of German Enemy Aliens in the United States during the First and Second World Wars', in Alien Justice: Wartime Internment in Australia and North America, ed. Kay Saunders and Roger Daniels, University of Queensland Press, Brisbane, 2000, pp. 66-79, here pp. 6771.

${ }^{9}$ For a comprehensive and detailed study of internment and the treatment of enemy aliens in Australia in World War I see Gerhard Fischer, Enemy Aliens: Internment and the Homefront Conflict in Australia, 1914-1920, University of Queensland Press, Brisbane, 1989. See also Nadine Helmi and Gerhard Fischer, The Enemy at Home: German Internees in World War I, UNSW Press/Historic Houses Trust, Sydney, 2011.

${ }^{10}$ L.F. Fitzhardinge, The Little Digger, 1914-1952, Angus \& Robertson, Sydney, 1979, pp. 73, 41.

${ }^{11}$ For more details see Ernest Scott, Australia during the War: The Official History of Australia in the War of 1914-1918, Angus \& Robertson, Sydney, 1936, pp. 137-40.

12 Cf. Donald Horne, In Search of Billy Hughes, Macmillan, Melbourne, 1979, p. 73.
} 
13 Commonwealth Parliamentary Debates, no. 89, pp. 12163-12179. Cf. also W. J. Hudson, Billy Hughes in Paris: The Birth of Australian Diplomacy, Nelson, Melbourne, 1978, pp. 127-8.

${ }^{14}$ See John Docker, 'Dilemmas of Identity: The Desire for the Other in Colonial and Post Colonial Cultural History', Working Papers in Australian Studies, no. 74, Sir Robert Menzies Centre for Australian Studies, London, 1992, which builds on his earlier and groundbreaking study The Nervous Nineties, Oxford University Press, Melbourne, 1991.

15 See Ann Curthoys and Stephen Muecke, 'Australia, for Example' in The Republicanism Debate, ed. Wayne Hudson and David Carter, UNSW Press, Kensington, NSW, 1993, pp. 177-200, p. 179.

16 For studies on the treatment of enemy aliens in World War II, see for example the work of Kay Saunders, War on the Homefront: State Intervention in Queensland, 1938-1948, University of Queensland Press, St. Lucia, QLD, 1993; and Raymond Evans, Loyalty and Disloyalty: Social Conflict on the Queensland Homefront, 1914-18, Allen \& Unwin, Sydney, 1987.

17 Mark McKenna, 'Anzac Day: How did it Become Australia's National Day?' in What's Wrong with Anzac? The Militarisation of Australian History, ed. Marilyn Lake and Henry Reynolds, UNSW Press, Sydney, 2010, pp. 110-34.

18 Graham Seal, “.... and in the morning ...": Adapting and Adopting the Dawn Service', Journal of Australian Studies, vol. 35, no. 1, 2011, pp. 49-63, p. 49 and p. 52.

19 Cf. K.S. Inglis, 'The Anzac Tradition', Meanjin Quarterly, vol. 24, no. 100, March 1965, pp. 25-44.

20 It may be of interest to note that, while Indigenous ex-servicemen regularly participate in Anzac Day marches and other events, there are also separate commemorations; for example the Redfern 'Coloured Diggers March' or a special Anzac ceremony under the auspices of the Aboriginal and Torres Strait Islander Veterans and Service Association of Australia (ATSIVAA) at the Aboriginal Anzac War Memorial Plaque at Mount Ainslie in Canberra, located behind the Australian War Memorial.

A position like that of Bruce Ruxton who-as president of the Victorian Returned Services League-protested against the participation of a newly formed 'Gay Ex-servicemen's Association' in the 1974 Melbourne Anzac Day commemoration, claiming that there were no 'queers or poofters' in the Australian armed forces, would be unthinkable today (cf. McKenna, p. 117). I might add here that the gay community in Sydney even has its own Anzac memorial today. It is the life-size statue of a World War I soldier with slouch hat, standing at ease in a coyly relaxed manner, right knee leisurely angled forward, right hand holding the rifle that rests on the ground to his side, and the other hand cheekily placed on his back pocket-a rather unusual pose, compared to the average Australian war memorial. The statue is located on a pedestal on the elevated grounds of Crown Street Public School, Surry Hills, giving the impression that the soldier is looking around surveying the neighbourhood. The crowds on Oxford and Darlinghurst Streets have adopted him as the 'Gay Digger'.

21 Phillip Coorey, 'Anzac Day represents all our nation is now-PM', Sydney Morning Herald, 26 April 2012. 
22 Hank Nelson, 'Gallipoli, Kokoda and the Making of National Identity', Journal of Australian Studies, no. 53, 1997, pp. 157-69, p. 157.

${ }^{23}$ Deane, Directions, p. 25.

${ }^{24}$ It is not clear whether Deane's choice of the term 'pioneer' is meant as a reference to the discussion by John Hirst of 'The Pioneer Legend', written as a corrective to Russel Ward's 'legend of the bush worker'. In any case, Hirst points out that the term pioneer was used rather loosely and could embrace a wide variety of people. He also emphasises that the pioneer legend 'solved the problem which formal historians could never overcome satisfactorily: the embarrassment of the convict origins of the nation'. The same is true, of course, for the Anzac legend which replaced both bushman and pioneer legend as national narrative. Cf. John Hirst, 'The Pioneer Legend', in his Sense and Nonsense in Australian History, Schwartz Publishing, Melbourne, 2006, pp. 174-96, p. 189.

25 Deane, Directions, p. 22.

26 McKenna, p. 126.

${ }^{27}$ Cf. John A. Moses, 'Anzac Day as Australia's All Souls' Day: Canon David John Garland's Vision for Commemoration of the Fallen', paper given at Christian Mission in the Public Square conference of the Australian Association for Mission Studies (AAMS) and the Public and Contextual Theology Research Centre of Charles Sturt University, Australian Centre for Christianity and Culture, Canberra, 2-5 October 2008. Moses, who rightly emphasises the religious foundations of the Anzac mythology, is currently working on a biography of Garland.

${ }^{28}$ McKenna, p. 127.

${ }^{29}$ Cf. Donald Horne, 'A Challenge to the Legend of Anzac' (25 April 1981), Sydney Morning Herald, 18 April 2006. The notion of a 'secular Easter' tends to downplay the importance of the original input of the churches in the creation of the Anzac rituals and mythology, notably the Anglican Church. The connection between Anzac and Easter was already made in the first Anzac memorial service on 25 April 1916 in the so-called Anzac Hostel in Cairo, in the sermon offered by the Senior Chaplain of the British contingent in Egypt, the Reverend Arthur Venables Caverley Horden. See John A. Moses, 'Anglicanism and Anzac Observance. The Essential Contribution of Canon David John Garland', PACIFICA, no. 19, February 2006, pp. 58-77, p. 68.

30 Donald Horne, 'A Challenge to the Legend of Anzac'.

31 General Sir John Monash, The Australian Victories in France in 1918, Hutchinson, London, 1920.

32 Marilyn Lake and Henry Reynolds (with Joy Damousi and Mark McKenna), What's Wrong with Anzac? The Militarisation of Australian History, UNSW Press, Sydney, 2010.

33 Seal, p. 56.

${ }^{34}$ As Charles Taylor has shown, the process of identity formation, within a horizon of competing claims of particular interests versus universal values, has become increasingly precarious in complex modern societies. Cf. Charles Taylor, Multiculturalism: Examining the Politics of Recognition, Princeton University Press, Princeton, 1994. 
35 See John Docker, 'Storm Troopers of Empire? Historical Representation in Breaker Morant, Naguib Mahfouz's Palace Walk and Other War Histories', History Australia, vol. 8, no. 1, 2011, pp. 67-88.

36 McKenna, p. 134.

37 Horne, 'A Challenge to the Legend of Anzac'.

38 Gerhard Fischer, 'In a New Play by West Australian Aboriginal Writer Mudrooroo' in The

Republicanism Debate, ed. Wayne Hudson and David Carter, UNSW Press, Kensington, 1993, pp. 226-9, p. 227.

39 Egon Erwin Kisch, Australian Landfall, Macmillan, Melbourne, 1969, p. 163.

40 McKenna, p. 116.

${ }^{41}$ Kisch, p. 168.

42 Kisch, p. 172.

${ }^{43}$ Robert Hughes, The Fatal Shore: The Epic of Australia's Founding, Vintage, London, 1987, p. 597. 44 Stephens, p. 123.

45 Moses, 'Anglicanism and Anzac Observance', p. 76. The alternative to a sober ceremony of mourning on Anzac Day seems to be what is being planned by the Commonwealth Government for the Anzac Centenary in 2015. Preparations to commemorate the landing at Gallipoli are already in full swing. The federal government has set up a national commission, the Anzac Centenary Advisory Board, to oversee the planning process, with ex-prime ministers Malcolm Fraser and Bob Hawke on board. The centenary website, sponsored by the Department of Veterans Affairs, is up and running; submissions are being sought on how to conduct commemorations, and hundreds have already been listed for the Commission's scrutiny. Some suggestions are predictable (a re-enactment of the landing at Gallipoli), others are predictably bizarre (a theatrical production 'Three Weeks in Spring-The Musical' to tour the nation's RSL clubs, or a 'Weekend in Trenches' as part of a 'Living History' experience for Australian school children). It is hard to say whether some of these ideas are meant as satire or in earnest. A soccer match between the Turkish and Australian national teams seems a more realistic proposal: sport as the continuation of war with other means. Despite all assurances that Anzac Day is all about dignified remembrance of lives lost and of heroic sacrifice in the service of an idea of Australian nationhood, we may well see a lot of other things happening. Australians love a party, as they say. And with such heavyweight bi-partisan political patronage and with widespread and largely uncritical media and popular support, Australians can expect 'an orgy of commemoration' (James Brown, 'On the 11th, remember the living', Sydney Morning Herald, 11 November 2011). The Gillard government has declared that the centenary will be observed not only on 26 April 2015, but from 2014-2018 (!).

46 Stephens, p. 9.

47 Quoted in Stephens, p. 149.

48 I am grateful to Ann Curthoys, John Docker and John Moses who read and commented on an earlier version of this essay. 